\title{
Disodium Cromoglycate(DSCG)が
}

\section{気管支喘息児の気道過敏性に及ぼす影響}

\author{
井上寿茂土居悟高松勇村山史秀 \\ 亀 田誠林田道 昭* 豊島 協一郎 \\ 大阪府立羽曳野病院アレルギー小児科，*：現大阪府立病院小児科
}

Key words：気管支喘息，気道過敏性，アセチルコリン吸入試験, disodium cromoglycate(DSCG)

要旨

disodium cromoglycate(DSCG) が気道過敏性に及ぼす影響を検討するため、比較的発作回数の少ない気管支 喘息児を対象に、D群（DSCGを 3 カプセル／日吸入する群；19例）とC群（予防的薬物投与を行わない不投薬 群；19例）に分け、アセチルコリン吸入試験を、治療開始前、治療開始 3 力月後（D群10例、C 群14例）、6力 月後（D群 7 例、C 群 5 例）、 1 年後（D群15例、C 群10例）に経時的に行った。アセチルコリン閾值は 3 カ月 後には D 群、C 群共有意な変動を示さなかったが、6力月後には両群とも上昇傾向を示した。一年後には $\mathrm{D}$ 群は 有意な上昇を示したが、C 群では有意な変動は認めなかった。DSCG吸入により気道過敏性の改善を得るには長 期間連用することが必要であることがわかった。また 1 年間の治療前後で末梢血好酸球数の変動をみると、D群 でのみ有意に末梢血好酸球数が減少しており、DSCGが気道局所の好酸球動態に影響を与え、気道過敏性の改善 に関与している可能性が考えられる。

気管支喘息では種々の特異的あるいは非特異的刺激 に対して気道過敏性が立進しており, 臨床的重症度と よく相関すると言われている1). 従って喘息治療の目 標は単に臨床症状をコントロールするだけではなく， この気道過敏性を低下させることに向けられるように なってきた2).これまで数多くの薬剤について喘息患 者の気道過敏性に及ぼす影響が検討され，抗コリン性 吸入剂(3)4)や経口抗アレルギー剂(5)6にについも気道過敏 性を低下させたとの報告が見られるが，有効性が確立 している薬剂はdisodium cromoglycate (DSCG) と吸 入ステロイド剂2)である.これまでのDSCGの気道過 敏性に対する影響に関する検討はヒスタミンやメサコ リンを用いたものが多く，観察期間も 2 〜 月月程度 の報告が大部分である7)、今回我々は小児気管支喘息 患児に対しアセチルコリンを用いて，気道過敏性に及 ぼすDSCGの影響を経時的に 1 年間にわたり検討した ので報告する。

Abbreviation : DSCG; disodium cromoglycate, RT-Ach; respiratory threashold of acetylcholine

\section{対象と方法}

当科外来通院中の比較的発作回数の少ない軽〜中等 症の気管支喘息児で，6〜14歳の安定して反復呼吸機 能検査可能な症例を対象とし, 非発作時呼吸機能が慢 性閉塞性の者 $\left(\% \mathrm{FEV}_{1}<75 \%\right)$ は対象から除外した。 対象児は1989年1月～1990年12月の間に本研究の対象 として登録された順に従い交互にDSCG群(D群) と不 投薬群 ( $\mathrm{C}$ 群)に分けた。両群共登録された時期に季節 的な片寄りはなかった。 D群には正しい吸入方法を十 分指導した後, DSCG $(20 \mathrm{mg})$ を 3 カプセル／日スピ ンヘラーにて定期的に吸入するように促し，一部の対 象児に対してはコンプライアンスを維持するため途中 から 2 カプセル/日とした．C群に対しては子防的薬 物投与は全く行わなかった。但し雨群とも抗原除去や 鍛鍊などの生活指導は十分に行い，発作時には必要に 応じ気管支拡張剂を短期間投与した。アセチルコリン 吸入試験は日本アレルギー学会吸入試験標準化法 ${ }^{8)} に$ 準じ，呼吸機能はミナト社製オートスパイロAS500を 用いて測定した，検查は原則的に治療開始前，開始 3 力月後, 6 力月後, 1 年後に実施したが, 検査前 4 週 間以内に喘息症状や気道感染兆候を認めた場合は検査 
を中止した，検査当日は12時間以上DSCG投与を中止 し，午後 $2 \sim 4$ 時の間に行った.アセチルコリン閾値 (RT-Ach)は $19 \times 2^{\mathrm{n}}$ として表した。またアセチルコ リン吸入試験実施時期に一致して末梢血好酸球百分率, 血清 $I g E$ 值, $\mathrm{FEV}_{1}$ を測定した. 統計学的検討は $\chi^{2}$ 検 定， $\mathrm{t}$ 検定またはぺア $\mathrm{t}$ 検定にて行なった。

結果

経時的にアセチルコリン吸入試験を再検できたのは D群19例，C群19例であった，両群間で試験開始時の 年齢, 性別, 喘息重症度, 喘息病型, 喘息罹病期間, 血清 $\operatorname{IgE}$ 值，末梢血好酸球百分率，\% $\mathrm{FEV}_{1}$ に差を認め なかった(表 1 ).

再検できた例は 3 力月後に $\mathrm{D}$ 群10例，C群14例， 6 力月後に $\mathrm{D}$ 群 7 例, $\mathrm{C}$ 群 5 例, 1 年後に $\mathrm{D}$ 群 15 例, $\mathrm{C}$ 群10例であった。 それぞれの時期に再検できたアセチ ルコリン閥值を試験開始前の值と比較してみると 3 カ 月後には $\mathrm{D}$ 群, $\mathrm{C}$ 群共有意な変動を認めなかった (表 2 a). 6 力月後には D 群, $\mathrm{C}$ 群共前值に比べやや上 昇傾向を示した $(\mathrm{p}<0.1)$ (表 $2 \mathrm{~b}) .1$ 年後には D 群 では有意な上昇が認められたが $(\mathrm{p}<0.01), \mathrm{C}$ 群の変 動は有意ではなかった (表 $2 \mathrm{c}$ )。なお 3 力月後, 6 力 月後, 1 年後に再検できた症例の前值は $\mathrm{D}$ 群と $\mathrm{C}$ 群で 統計学的な差はなかった。

1 年後に再検できた各症例毎のアセチルコリン閾値 の変化をみると， $\mathrm{D}$ 群では 15 例中 10 例が上昇， 3 例が 不変，2例が低下を示した(図左)。これに对し，C群 では10例中 6 例が上昇， 1 例が不変， 3 例が低下を示 した(図右).
表 1 対象患者背景

\begin{tabular}{|c|c|c|}
\hline & D S C G 群 & 不投薬群 \\
\hline 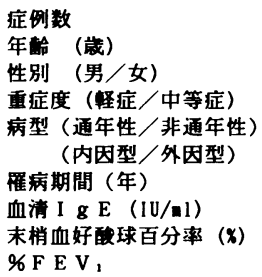 & $\begin{array}{c}19 \\
9.9 \pm 2.6 \\
8 / 11 \\
10 / 9 \\
2 / 17 \\
1 / 18 \\
3.9 \pm 3.0 \\
503(217 \sim 1164) \\
11.1 \pm 5.3 \\
98.8 \pm 14.9\end{array}$ & $\begin{array}{c}19 \\
9.6 \pm 1.5 \\
10 / 9 \\
12 / 7 \\
0 / 19 \\
1 / 18 \\
4.7 \pm 3.5 \\
572(176 \sim 1863) \\
11.9 \pm 7.2 \\
97.2 \pm 14.9\end{array}$ \\
\hline
\end{tabular}

表 2 アセチルコリン閾值 ${ }^{*}$ の経時的変化

\begin{tabular}{|c|c|c|c|c|}
\hline & 例数 & 前 & 3 力月後 & \\
\hline D S C G 群 & 10 & $4.5 \pm 1.3$ & $5.5 \pm 2.2$ & n. s. \\
\hline 不投䔞群 & 14 & $5.2 \pm 1.7$ & $5.4 \pm 1.9$ & n. s. \\
\hline \multicolumn{5}{|l|}{ b. } \\
\hline & 例数 & 前 & 6 力月後 & \\
\hline D S C G 群 & 7 & $4.7 \pm 1.5$ & $5.9 \pm 1.6$ & $p<0.1$ \\
\hline 不投萝群 & 5 & $5.2 \pm 1.3$ & $6.2 \pm 1.3$ & $p<0.1$ \\
\hline \multicolumn{5}{|l|}{ c. } \\
\hline & 例数 & 前 & 1 年後 & \\
\hline D S C G 群 & 15 & $4.2 \pm 1.6$ & $5.5 \pm 1.6$ & $p<0.01$ \\
\hline 不投薬群 & 10 & $5.3 \pm 1.6$ & $5.8 \pm 3.1$ & n. s. \\
\hline
\end{tabular}

a，b，cいずれも D S C G 群と不投薬群の前值に

有意差はなかった。

* : RT-Achは $19 \times 2$ として表し、nについて検討した。

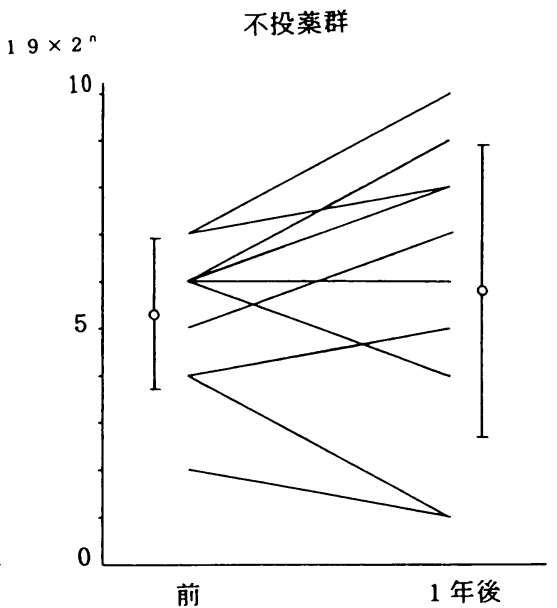

図アセチルコリン閾值の 1 年後の変化 
次に 1 年後に再検できた例について前後で検查成績 の変化をみたところ, 血清 $I g E$ 值や\% $\% \mathrm{FEV}_{1} に$ 変動はな かった。ただ末梢血好酸球百分率は C 群では統計学的 に差がなかったが，D群での減少は有意であった $(\mathrm{p}$ $<0.05)$ (表 3$)$ ．そこで 1 年間でのアセチルコリン間 值の変動と末梢血好酸球百分率の変動について関連性 を検討したが有意ではなかった（表 4 ）。

気道過敏性は臨床的重症度, すなわち喘息発作の強 さと頻度によって影響を受ける可能性が高いので，1 年間の発作点数とアセチルコリン閾值の変動との関連 性を検討した(表 5 )。なお 1 年間の発作点数は 1 日の 発作を大発作 3 点, 中発作 2 点, 小発作 1 点, 喘鳴 0 . 5点として点数化し， 1 年間の発作日数を喘息日記の 記載から求め, その合計点として表した。ほほ寛解状 態と考えられる 5 点未満の群とそれ以上の群に分けて アセチルコリン閾值の変動をみると, 発作の少ない群 では発作の比較的多い群に比し, 有意に高頻度でアセ チルコリン閾值の上昇が認められた $(\mathrm{p}<0.05)$. 特に $\mathrm{D}$ 群でその傾向が著明であった $(\mathrm{p}<0.01)$.

表 $3 \quad 1$ 年間観測例での検查成績の変動

\begin{tabular}{|c|c|c|c|c|}
\hline & & 前 & 1 年後 & \\
\hline RT-Ach & DSCG群 & 4. $2 \pm 1.6$ & $5.5 \pm 1.6$ & $p<0.01$ \\
\hline$\left(19 \times 2^{\circ}\right)$ & 不投莧群 & $5.3 \pm 1.6$ & $5.8 \pm 3.1$ & n. s. \\
\hline \multirow[t]{2}{*}{$\log (\lg E)$} & DSCG群 & $2.76 \pm 0.37$ & $2.72 \pm 0.35$ & n. s. \\
\hline & 不投莱群 & $2.68 \pm 0.53$ & $2.55 \pm 0.46$ & n. s. \\
\hline \multirow{2}{*}{$\begin{array}{c}\text { 末梢血好韵球 } \\
(\mathbf{X})\end{array}$} & DSCG群 & 12. $3 \pm 5.2$ & $9.7 \pm 4.3$ & $p<0.05$ \\
\hline & 不投菜群 & $14.0 \pm 9.2$ & $9.6 \pm 6.2$ & n. s. \\
\hline \multirow[t]{2}{*}{ XFEV, } & DSCG群 & $99.8 \pm 11.6$ & $100.3 \pm 15.6$ & n. s. \\
\hline & 不投莱群 & $95.4 \pm 14.6$ & $94.6 \pm 19.3$ & n. s. \\
\hline
\end{tabular}

表 4 アセチルコリン間値と末梢血好酸球百分率の関係

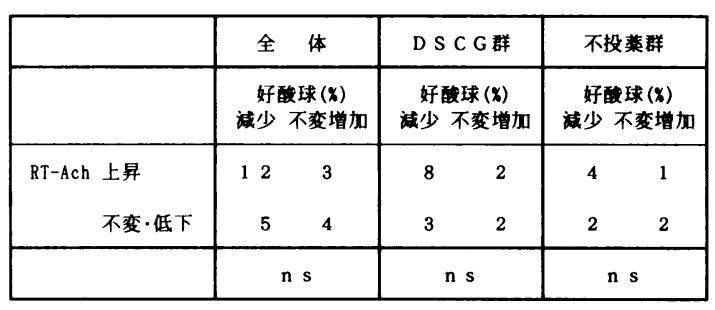

表 5 アセチルコリン閾値と臨床症状の関係

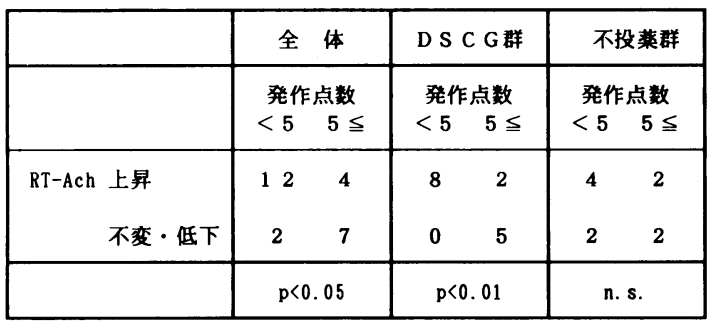

発作点数：1年間の発作を 1 日毎に大発作 3 点、中発作 2 点、 小発作 1 点、喘鳴 0.5 点として合計点数で表した。

\section{考察}

気管支喘息の病態については未だ十分に解明された とはいえないが, 気道過敏性の克進には気道の炎症が 強く関与していると考えられている9．従って喘息の 治療は炎症を抑制し, 気道過敏性を低下させることに 向けられることが必要である29910).この主旨に沿った 抗炎症作用を有すると広く認められている主な薬剤は 現在のところDSCGと吸入ステロイド剤である ${ }^{299)}$ 。そ して薬剤の安全性を考慮し, 小児における喘息予防薬 としての第一選択薬はDSCGと考えられており ${ }^{10111)}$, 広く臨床の場で用いられている. しかしDSCGの作用 機序については未だ不明の点も多い(2). 細胞膜の安定 化による肥満細胞からの化学伝達物質遊離抑制13) や, 他の炎症細胞の抑制 ${ }^{1415)}$ ，軸索反射の抑制16) などが推 測されている.DSCGの気道過敏性に対する影響につ いてはこれまでの報告によると 6 ～12週間の投与でヒ スタミンやメサコリンに対する過敏性が低下するとす るものが多い7).アセチルコリンを用いた検討では

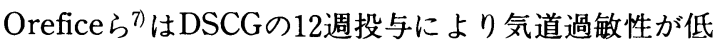
下したと報告しているのに対し, Haberら ${ }^{17)}$ は変動が なかったと報告している.我々の成績はDSCG吸入が 3 カプセル／日と他の報告に比べ少量であることも影 響しているかも知れないが， 3 力月後，6力月後の検 査では不投薬群と差はなく，1 年後にはじめて有意差 を認めた。しかしいずれの時期においてもアセチルコ リン閾值の平均は上昇しており, 症例数が少ないため 3 力月後, 6 力月後には有意な変動とならなかった可 能性もある。 また気道過敏性はDSCG治療により発作 が消失してもDSCG治療開始前の発作頻発時期に一致 して六進し, 発作出現が少ない時期に低下するという 年内変動が認められたとの報告18)もあり, 病型が非通 年性の症例が多く, 治療開始時期も一定でなかったた 
め季節変動の影響により 3 力月後, 6 力月後には有意 な変動とならなかった可能性もある．1 年以上の長期 間にわたってDSCGの気道過敏性に及ぼす影響につい て検討した報告は極めて少なく18191200)，対照群を置い た検討は見あたらない. 我々の検討はプラセボの投与 は行っていないが, 不投薬群を対照として検討し, D 群では 1 年後に有意な気道過敏性の低下を認めたのに 対し，C群では改善が認められず，DSCGが喘息児の 気道過敏性を低下させるように作用していることが示 された．また例数が少ないので断定することは困難で あるが，C群では 1 年間症状がほとんどなくても気道 過敏性が必ずしも低下しなかったのに比べ，D群では 症状の少なかった群で有意に気道過敏性が低下してい ることから, DSCGの気道過敏性に対する影響は単に 喘息症状がコントロールされることによる二次的効果 ではなく, DSCGの気道過敏性に関与する因子に対す る直接的効果の可能性が考之られた。

気管支喘息における気道の炎症反応には好酸球が強 〈関与しており (921)22)，末梢血好酸球数の変動と気道過 敏性や呼吸機能検查結果との関連性についての報告が みられる23．そこで 1 年間観察できた例で末梢血好酸 球百分率の変動を検討したところ， D群，C群ともに 平均值は 1 年後に減少していたが， D群のみ統計学的 に有意差を認めた。しかし気道過敏性の変動とは相関 しなかった. DSCGが好酸球の動態に対し直接的ある いは間接的に影響を与之神，これを介して気道過敏性 の変動に寄与している可能性2)については更に多数例 で検討することが必要であろう。

気道過敏性は抗原暴露を徹底的に回避することによ り低下することが報告されているが24)，今回対照とし て用いた C 群では 1 年間で有意な変動を示すことはな かった. 外来治療の中で抗原除去指導を行っているが， 抗原除去が十分でなかったのか，あるいは抗原除去治 療の限界であるのか不明であり，このような軽症例に ついても臨床症状のみならず，気道過敏性の面からの 長期的観察を行い, 抗原除去を含めた生活指導が気道 過敏性に及ぼす影響についての検討が必要と思われた。

稿を終えるにあたり御校閲いただいた大阪府立羽电 野病院岸本進院長に深謝いたします。なお本論文の要 旨は第23回日本小児呼吸器疾患学会ならびに第28回日 本小児アレルギー学会において発表した。

\section{文献}

1) Hargreave, F.E., Ryan, G., Thompson, N.C.,
O' Byrne, P. M. , Latimer, K. , Juniper, E. F. and Dolovich, J.: Bronchial responsiveness to histamine or methacholine in asth ma: measurement and clinical significance. J. Allergy Clin. Immunol. 68,347-355, 1981.

2 ) Woolcock, A. J., Salome, C. M. and Keena, V. A. : Reducing the severity of bronchial hyperresponsiveness. Am. Rev. Respir.Dis. 143, S75-S77, 1991.

3 ) 望月博之, 三橋將人, 田島公夫, 徳山研一, 森川 昭広, 黒梅恭芳：アトロベント®の気道過敏性に及 ぼ寸影響について 一アストグラフを用いたメサコ リン吸入試験による検討一。アレルギー34,96-100, 1984.

4 ) 江頭洋祐, 浦田ゆかり：気管支喘息患者に対する 抗コリン性吸入剂の長期連用効果の検討 - とくに 気道過敏性との関連について一。臨床と研究 61 , 2007-2013, 1984 .

5 ) Girard,J.P.: Ketotifen and bronchial hyperreactivity in asthmatic patients. Clin Allergy $11,449-452,1981$.

6 ) 鈴木一, 田中一正, 金重博司, 中神和清, 野口英 世：気道過敏性に対するTranilastの影響.アレル ギーの臨床. 6,1029-1033,1986.

7 ) Hoag, J.E. and McFadden,E.R.: Long-term effect of cromolyn sodium on nonspecific bronchial hyperresponsiveness: a review. Ann. Allergy 66,53-63, 1991 .

8 ) 牧野荘平, 小林節雄, 宮本昭正, 信太隆夫, 高橋 昭三, 可部順三郎, 中島重德：気管支喘息および過 敏性肺臟炎における吸入試験の標準法.アレルギー 31,1074-1076, 1982 .

9) Barnes, P.J.: New concepts in the pathogenesis of bronchial hyperresponsiveness and asthma. J. Allergy Clin.Immunol. 83, 1013-1026, 1989.

10) National Heart, Lung, and Blood Institute : Guideline for the diagn osis and management of asth ma VII. Management of asth ma. J.Allergy Clin.Immunol. 88 (part 2) ,477-492, 1991.

11) Asthma: a follow up statement from an international pediatric asthma consensus group. Arch.Dis.Child. $67,240-248,1992$.

12) 本岡弘：ジソジウムクロモグリケート(インター ル®) 一クロモグリク酸ナトリウムの薬理作用一。 喘息 2,21-27, 1989. 
13) Cox, J.S.G.: Disodium cromoglycate (EPL 670 , Intal): a specific inhibitor of reaginic antibody-antigen mechanisms. Nature 216,1328$1329,1967$.

14) Diaz, P. ,Galleguillos, F. R. , Gonzalez, M.C., Pantin, C.F.A. and Kay, A. B. : Bronchoalveolar lavage in asthma: the effect of disodium cromoglycate (cromolyn) on leukocyte counts, immunoglobulins, and complement. J.Allergy Clin. Immunol. 74, 41 $-48,1984$.

15) Kay, A. B. , Walsh, G. M., Moqbel, R., MacDonald, A.J., Nagakura, T., Carroll, M.P., and Richerson, H. B.: Disodium cromoglycate inhibits activation of human inflammatory cells in vitro . J. Allergy Clin. Immunol. 80,1-8, 1987.

16) Dixon, M., Jackson, D.M. and Richards, I.M.: The action of sodium cromoglycate on "C" fibre endings in the dog lung. Br.J.Pharmacol. 70,11-13, 1980 .

17) Haber, P., Geyer, K. and Burghuber, O.C.: Long-term treatment with disodium cromoglycate does not alter bronchial hyperreactivity in patients with perennial bronchial asthma. Respiration $55,44-49,1989$.

18）加納芳郎：DSCG (Disodium Cromoglycate) 治療 とメサコリン過敏性についての検討.アレルギー 30, 197-205, 1981.

19) Dickson, W.: A one year's trial of Intal ${ }^{\circledR}$ compound in 24 children with severe asthma. In "Disodium cromoglycate in allergic airways disease" edited by Pepys, J. and Frakland, A. W., London: Butterworths: pp105-120,1970.

20) Watanabe, H.: The effect of DSCG agaist bronchial hyperreactivity in asthmatic children. NER. Allergy Proc. 9,354, 1988.

21) Gleich, G.J.: The eosinophil and bronchial asthma: Current understunding. J. Allergy Clin . Immunol. 85, 422-436, 1990.

22) Ohashi, Y., Motojima, S., Fukuda, T. and Makino, S. : Airway hyperresponsiveness, increased intracellular spaces of bronchial epitherium, and increased infiltration of eosinophils and lymphocytes in bronchial mucosa in asthma. Am. Rev. Respir. Dis. 145, 1469-1476, 1992.

23) Griffin ,E., Hakansson, L., Formgren, H. , Jorgensen, K., Peterson,C. and Venge,P.: Blood eosinophil nummber and activity in relation to lung function in patients with asth ma and with eosinophilia. J. Allergy Clin.Immunol. 87,548$57,1991$.

24) Platts-Mills, T.A.E., Tovey, E. R., Mitchell, E. B., Moszoro, H. , Nock, P. and Wilkins, S.R. : Reduction of bronchial hyperreactivity during prolonged allergen avoidance. Lancet $2,675-678,1982$.

\section{THE EFFECTS OF DISODIUM CROMOGLYCATE ON BRONCHIAL HYPERRESPONSIVENESS IN CHILDREN WITH ASTHMA \\ Toshishige Inoue, Satoru Doi, Isamu Takamatsu, Norihide Murayama, Makoto Kameda, Michiaki Hayashida, Kyoichiro Toyoshima Osaka prefectural Habikino hospital Department of Peadiatric Allergy}

We studied the effects of disodium cromoglycate(DSCG) on bronchial hyperresponsiveness in 38 mild asthmatic children. The subjects were divided into two groups; patients of group D inhaled $20 \mathrm{mg}$ of DSCG 3 times daily and group C had no prophylactic drugs. Acetylcholine inhalation challenge test was performed repeatedly before and after 3 months of treatment (10 cases in group D and 14 cases in group C), 6 months ( 7 in group D, 5 in group C) and 12 months ( 15 in group D, 10 in group C). Respiratory threshold of acetylcholine (RT-Ach) did not significantly change after 3 months of treatment and slightly increased after 6 months of treatment in both groups. After 12 months of treatment, RT-Ach significantly increased in group D, but did not change in group C. We concluded that long-term use of DSCG decreased the bronchial hyperresponsiveness in asthmatic children. The number of eosinophils in 
peripheral blood significantly decreased after 1 year of treatment only in group D. From this results, we guess that DSCG might have the effect on eosinophils contributing to the inflammatory process of asthma and protect against the increase of bronchial hyperresponsiveness.

(Accepted: November 27,1992) 